\title{
A imersão oculta em plataformas online: uma experiência antropológica a partir dos estudos de recepção
}

\author{
LUIZ Augusto Mugnai VieIRA Junior \\ Universidade Estadual Paulista Júlio de Mesquita Filho, Marília, São Paulo, Brasil \\ gutomug@gmail.com
}

DOI 10.11606/issn.2316-9133.v29i2pe175275

resumo A partir da experiência de um estudo antropológico que consistiu na confecção de uma pesquisa de doutorado sobre a recepção da transexualidade nas mídias digitais, o presente artigo tem como objetivo descrever sobre os procedimentos de imersão em plataformas online, do mesmo modo, refletir a prática e o comportamento online da antropóloga de ser observadora oculta digital. Para tal, descrevo de forma mais detalhada sobre como foi proceder durante quatro anos em campo online fornecendo reflexões sobre a observação antropológica no campo digital e seus artefatos de pesquisa para a sua realização. A sociedade e a cultura têm sido marcadas e intensificadas pelas mídias digitais; é o anúncio do digital constituindo a vida cotidiana. Frente a esse cenário, descrever o campo online, observar o digital e refletir sobre as relações sociais intermediadas por uma tela de computador ou de celular têm sido, cada vez mais, um exercício recorrente e desafiante para os estudos sócio- antropológicos.

palavras-chave Imersão oculta. Plataforma online. Mídias digitais. Recepção.

\section{Hidden immersion in online platforms: an anthropological experience from} the reception studies

abstract The article aims to describe the procedures of immersion in online platforms and reflect the anthropologist's online practice and behavior of being a hidden digital observer. It is based on the experience of an anthropological study regarded to the preparation of a doctoral research on the reception of transsexuality in digital media. That said, the article describe how it was to proceed for four years in the online field, producing reflections on anthropological observation in the digital field and its research artifacts for its 
realization. Facing the announcement of the digital constitution of everyday life in society and culture, the article attempts to describe the online field, observing the digital and reflecting on social relations mediated by a computer or cell phone screen have been, increasingly, a recurring and challenging exercise for socio-anthropological studies.

keywords Hidden immersion. Online platform. Digital media. Reception.

Inmersión oculta en plataformas online: una experiencia antropológica de

\section{los estudios de recepción}

resumen A partir de la experiencia de un estudio antropológico que consistió en la elaboración de una investigación doctoral sobre la recepción de la transexualidad en los medios digitales, este artículo tiene como objetivo describir los procedimientos de inmersión en plataformas online, de igual forma, para reflejar la práctica en línea del antropólogo y comportamiento de ser un observador digital oculto. Para ello, describo con más detalle cómo se iba a proceder durante cuatro años en el campo online, aportando reflexiones sobre la observación antropológica en el campo digital y sus artefactos de investigación para su realización. La sociedad y la cultura se han marcado e intensificado por los medios digitales; es el anuncio de lo digital que constituye la vida cotidiana. Ante este escenario, describa el campo online, observar lo digital y reflexionar sobre las relaciones sociales mediadas por una computadora o pantalla de teléfono celular han sido, cada vez más, un ejercicio recurrente y desafiante para los estudios socioantropológicos.

palavras clave Inmersión oculta. Plataforma online. Medios digitales; Recepción.

\section{Introdução}

Em um mundo tecnologicamente mais digital, a antropologia parece estar sendo eticamente instigada e teórico-metodologicamente desafiada em direção às tramas digitais. Tomando emprestada a ideia de Daniel Miller e Horst Heather (2012), os estudos antropológicos sobre o campo digital e/ou online ou a chamada antropologia digital tem se tornado cada vez mais um oportuno caminho para entender a sociedade contemporânea.

O presente artigo é resultado de pesquisa de doutorado intitulada "Quantas curtidas merece essa trans?”, que, em um esforço de compilação e reflexão resultou em inúmeros 
dados quanti-qualitativos de caixas de comentários, prints $^{1}$, tabelas, palavras-chave, gráficos e outros artefatos para se produzir no digital ${ }^{2}$.

Tais levantamentos realizados pela pesquisa foram com o principal objetivo de perceber a recepção da transexualidade nas mídias digitais. ${ }^{3}$ Mas, como fazer isso num ambiente online? Para entender esse processo dinâmico da receptividade no online/digital, o estudo antropológico usou como método a imersão em plataformas online e os estudos de recepção. Então, antes de detalharmos cada um desses métodos investigativos e falar das suas estratégias no digital/online, é interessante destacar que a imersão, assim sintetiza Marilyn Strathern (2014), é o "momento da observação" no qual se estabelece o contato com o objeto/sujeito observado. É o momento de tecer as observações, descrições e considerações preliminares a respeito do vivenciado que serão analisadas, aprofundadas, questionadas e inter-relacionadas num segundo momento distante do campo de observação preliminar. Por isso que o processo imersivo de levantar e escolher quais dados podem servir para a problemática de pesquisa já é, de certa forma, uma pré-análise. Da mesma forma, vamos perceber que os estudos de recepção ${ }^{4}$ também são utilizados tanto para levantar os dados como para ajudar na análise desses; a sua importância nesses dois momentos da pesquisa assim como a imersão foram estratégias fundamentais para compreender a dinâmica no digital.

Como vimos, para entender a recepção da transexualidade nas mídias digitais houve um meio utilizado para fazer tal investigação, é nesse ponto sobre a forma usada para a feitura do estudo antropológico no online que o presente artigo pretende pensar, isso quer dizer, discutir o caminho teórico metodológico usado no campo digital. Dessa maneira, proponho neste texto, três pontos que se conectam entre si: a descrição do campo online, a

\footnotetext{
${ }^{1}$ São imagens capturadas daquilo que se vê na tela do celular ou do computador naquele momento.

${ }^{2}$ Larissa Pelúcio; Heloisa Pait; Thiago Sabatine (2015) mostram o quanto as relações da contemporaneidade marcadas pelo uso cada vez mais intensificado das mídias digitais têm chamado a atenção das Ciências Sociais, não somente pelos desafios teórico e metodológico do campo digital, mas das relações de gênero e sexualidade que tem atravessado o aparato digital.

3 Conforme Richard Miskolci (2011: 12) as mídias digitais "são uma forma de se referir aos meios de comunicação contemporâneos baseados no uso de equipamentos eletrônicos conectados em rede, portanto referem-se - ao mesmo tempo - à conexão e ao seu suporte material”. O pesquisador destaca que existem diversas formas de equipamentos (computadores de mesa, portáteis, celulares ou tablets) como de se conectar (rede telefonia fixa ou rede móvel de celular). Todas essas formas e meios usados para se conectar se entrecruzam em diversas frequências de acesso, formas de mobilidade, velocidades de conexão e tipos de redes em que o usuário vai estar inserido.

${ }^{4}$ A recepção ou receptividade, que se refere ao ato ou efeito de receber, é tanto uma categoria de análise como uma antiga preocupação nos estudos antropológicos e de comunicação. Para Adriana Braga e Édison Gastaldo (2009), a Escola de Chicago, grupo de pesquisadores que surgiu na década de 1920, do século passado, nos Estados Unidos tem fornecido um importante "legado teórico e metodológico das ciências sociais" para o campo dos estudos de recepção e consumo midiáticos contemporâneos.
} 
observação do/no online e os desafios de se fazer uma pesquisa pela internet ou pelas mídias digitais.

\section{A descrição do campo online: Globo.com e Facebook}

As mídias digitais dinamizam relações, ampliam debates e democratizam informações, pois, conforme o sociólogo Richard Miskolci (2011), possibilitam novas formas de socialização e que trazem novos impactos à vida cotidiana contemporânea, entre eles, nas subjetividades, nas relações interpessoais e nas coletividades. Diferentes das mídias anteriores, as mídias recentes edificam e tendem a impulsionar o protagonismo ${ }^{5}$ de qualquer pessoa que se coloca na rede, ademais, elas têm contribuído cada vez mais para dar voz aos novos atores sociais dentro de uma nova dinâmica assentada por transformações técnicas, sociais e subjetivas e que sejamos produtores de conteúdo.

A pesquisa sobre as mídias digitais é um campo fértil para as ciências sociais uma vez que o uso delas proporciona novos olhares e questionamentos das relações sociais. Além disso, apresenta desafios metodológicos e analíticos no campo científico socioantropológico. Entretanto, mesmo as mídias digitais se mostrando um objeto de investigação propício e chamando atenção, até uma década atrás, a avaliação é que havia pouca produção de estudo nas ciências sociais (MISKOLCI 2011). É ao buscar novas estratégias e produzir antropologicamente sobre o campo online que se observa as mídias digitais tornarem-se, cada vez mais, um parâmetro de opinião pública. Por isso as fontes utilizadas para entender a recepção da transexualidade neste trabalho foram de comentários de matérias que tangem a transexualidade do Portal Globo.com e de outros comentários, postagens e compartilhamentos de dois grupos da rede social digital Facebook. Vale destacar: a definição das fontes na pesquisa foi uma forma de estabelecer uma possibilidade de delimitação do campo online, uma vez que, este é estruturalmente composto por links que levam a outros links e que assim formando um sistema complexo de links, torna-se um desafio para o pesquisador/a no digital como será discutido mais adiante. Ademais, a escolha e a descrição do campo já fornecem uma rica análise para se problematizar o digital.

O uso dos comentários do Portal Globo.com foi por se tratar de uma das cinco plataformas mais acessada do Brasil $^{6}$ e estar entre os mais significativos portais de notícias

\footnotetext{
${ }^{5}$ De um receptor ativo e não passivo, uma vez que a recepção, mais do que a forma de como uma informação foi recebida, apreendida e compreendida é principalmente produtora de sentidos (MARTÍN-BARBERO 1987). ${ }^{6}$ Segundo Alexa Internet (2018) que tem como sua principal missão a mensuração de acessos de usuários que visitam um site, o Portal Globo.com é o Portal da internet de língua portuguesa mais acessado no mundo. De acordo com os dados da companhia o Globo.com (portal) ocupa atualmente o quinto lugar dos sites mais clicados no Brasil ficando atrás do: 1 - Google.com.br (buscador); 2 - Youtube.com (rede social de vídeos); 3 Google.com (buscador) e do 4 - Facebook.com (rede social). Em 2014, o Portal Globo.com obtinha o sexto lugar, depois do Portal da UOL, mas no ano seguinte, em 2015, o Portal das Organizações Globo conquistou a quinta colocação e atualmente mantem a posição (ALEXA 2018).
} 
do País, no qual a interatividade é possível, isto é, leitores/as podem deixar comentários abaixo nas matérias utilizando se de nicknames (apelidos). O Portal Globo.com faz parte do conglomerado Globo, a rede de televisão brasileira aberta de maior audiência no Brasil e tem uma extensão que vai da TV à editora, perpassando jornais impressos como O Globo até plataformas na rede mundial de computadores.

O Globo.com é o Portal mais acessado no Brasil. Existem outros portais que têm expressão de acessos no país, entre os mais antigos estão: o Portal UOL (do grupo Folha e criado em 1996); o Portal Terra (empresa brasileira pertencente ao conglomerado espanhol Telefônica que foi lançado em 1999) e o Portal Yahoo (criado em 1994 e sediado na Califórnia - Estados Unidos).

Segundo o antropólogo Airton Luiz Jungblu os portais "são aqueles vultuosos sites onde estão disponibilizadas grandes quantidades de informação e recursos da web (por exemplo: AOL nos EUA, UOL e Terra no Brasil)” (2004: 104). Em relação aos processos de editoração, os portais de internet são sobremodo análogos aos meios de comunicação de massa não mediados por computadores, como por exemplo, o do impresso ou televisivo. Entretanto, de maneira geral, na comunicação mediada por computador "o receptor" está inserido em uma rede de variadas informações que o torna menos passivo e mais exigente por conta deste poder de buscar, acessar e comparar as diferentes versões de uma dada informação nos mais numerosos sites em trânsito pela web (JUNGBLU 2004). Para Miskolci (2016), as mídias de massas como a televisão são consideradas mídias verticais, pois possibilitam pouca interatividade diferente das mídias digitais como a internet, que por sua maior possiblidade de interação são consideradas mídias horizontais.

De acordo com o próprio Globo.com, os portais são:

Páginas na internet que servem como ponto de acesso direto a um conjunto de serviços e informações (...) podem ser horizontais permitindo acesso a vários tipos de informação e serviços - ou verticais concentrando links para conteúdo sobre um assunto específico (GLOBO, 2008, s.p).

O Portal Globo.com é público e maior parte dele gratuito. Algumas matérias são restritas a assinantes, como por exemplo, do site $\mathrm{O}$ Globo. Tal área restrita começou em 2010. O Portal é formado por cinco grandes pilares: G1, Ge, Gshow, Tech e Vídeos. Cada pilar possui uma cor. O do G1 que compõe páginas do jornalismo é vermelha. O Ge sobre o mundo esportivo é verde. O Gshow sobre entretenimento como a vida dos famosos é laranja. O Tech, o site de tecnologia do Portal, tudo sobre o digital, é cinza. E por fim o Vídeo na cor azul disponibiliza conteúdo audiovisual. A composição das matérias no Globo.com tem 
um layout visual em que a matéria de maior destaque fica localizada no canto esquerdo superior com letras em fonte maior que outras. De 2016 adiante a plataforma passou a ser dividida em três colunas: à esquerda estão as matérias do G1 (vermelha); na do meio as do Ge (verde) e à direita as do Gshow (laranja). As demais vão aparecendo logo abaixo das três colunas. E no final da página do Portal vai haver "TOP GLOBO tá todo mundo clicando...” que são as três colunas das matérias mais acessadas do G1, Ge e Gshow.

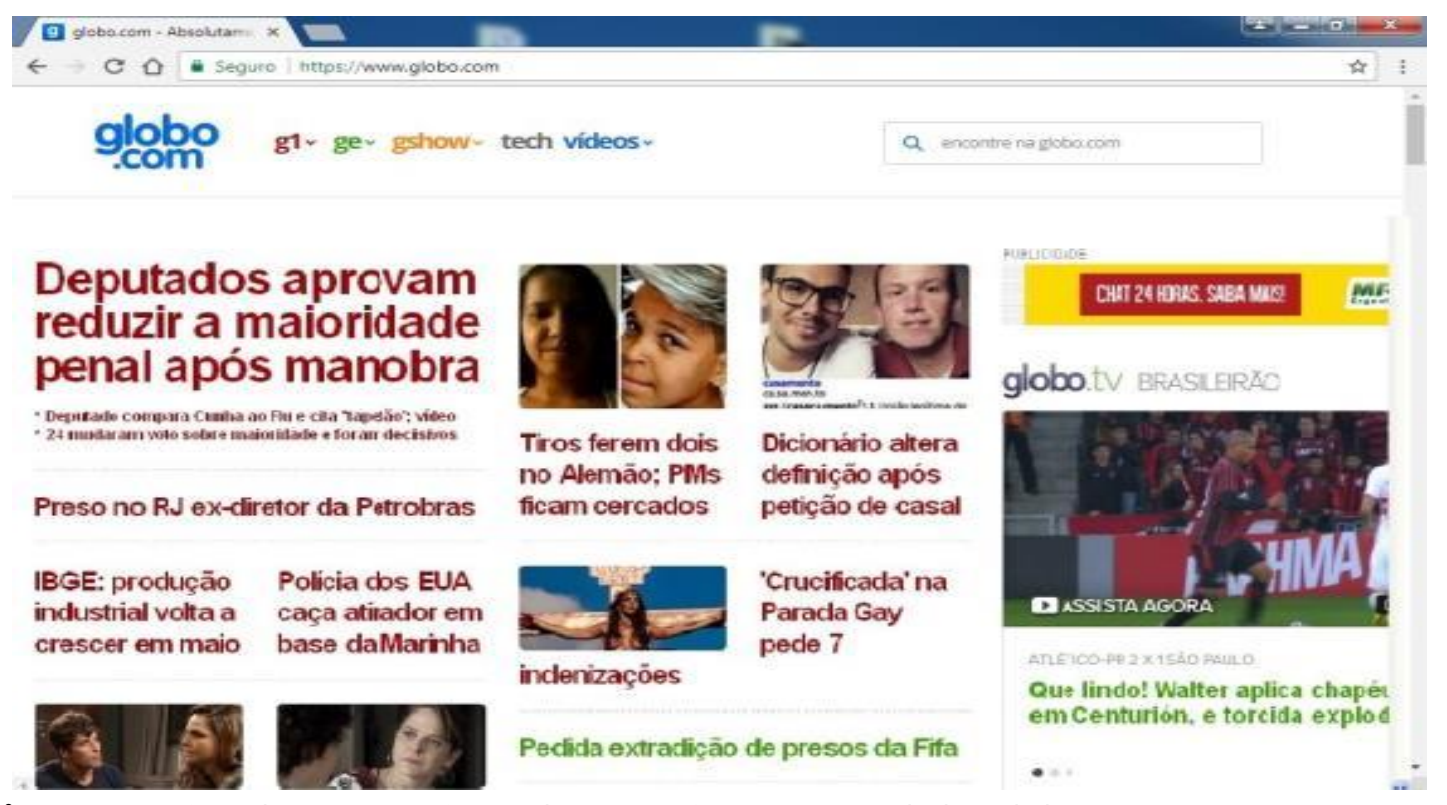

Figura 1. Print da composição das notícias no Portal da Globo.com. Fonte: GLOBO. Portal de notícias. Disponível em:< http://www.globo.com/>. Acesso em: 02 jul. 2015.

Geralmente as reportagens do G1 (vermelha) são as que se destacam mais, porém, às vezes, principalmente nas quartas-feiras e nos domingos à noite, e também em época de Copa do mundo, Olímpiadas e decisões de Campeonatos. O Ge (verde) aparece em destaque, e, muito esporadicamente, o Gshow (laranja) ganha realce, o que acontece nas estreias e finais das edições do programa Big Brother Brasil ou ainda das novelas da emissora. ${ }^{7}$ Quando acontece algo de importância e de urgente divulgação o Portal traz no seu topo em destaque uma tarja preta anunciando a recente notícia.

Um dado importante encontrado na observação imersiva, entre 2015 e 2018, é que nenhuma matéria sobre a transexualidade ocupou o lugar de principal destaque no Portal Globo.com (no canto superior esquerdo e com fonte maior); no máximo com evidência e

\footnotetext{
${ }^{7}$ Ao longo tempo, a interface do visual Globo.com foi passando por alterações e se modificando. Os pilares que formam o Portal ganharam cores em 2006, entretanto a cor do pilar das notícias inicialmente era azul até 2007, quando teve a aparência mudada e ficou vermelho. Nota-se que a composição e a aparência que atualmente o Portal Globo.com possui inicia em 2008. Como o Globo.com o Facebook desde o seu surgimento também sofre mudanças e atualizações tanto nos seus aspectos visuais como nas suas funcionalidades.
} 
perto da matéria principal como exposto na Figura 01- a reportagem sobre atriz transexual Viviany Beleboni "Crucificada na Parada Gay”. Como foram observadas outras matérias sobre a transexualidade tiveram destaque no Portal, mas não como a principal; outras não apareceram com notoriedade no Globo.com, se restringindo apenas as plataformas de sites que compõem e formam o Portal.

$\mathrm{Na}$ versão mobile, acessada em smartphones, o layout do Portal é um pouco diferente. Ele possui apenas uma coluna que tem no seu topo o logo Globo.com em azul e em seguida embaixo os cinco pilares citados. No smarthphone há apenas uma coluna que vai sendo dividida por linhas que são o G1, Ge, Gshow, Tech e os Vídeos. O Globo.com estreou o Portal para iPhone e outros smartphones em 2008. Para acessar o Portal móvel os telefones celulares com acesso à internet devem digitar o seguinte endereço: m.globo.com (GLOBO 2008b).O primeiro smartphone foi comercializado em 2007 de acordo com Miskolci (2014), tal invenção é fruto do surgimento do microchip de silicone no parque tecnológico do Vale do Silício, concentração de diversas empresas de alta tecnologia da informação e computação. Segundo o pesquisador, o smarthphone devido ao microchip siliconado, não somente modificou profundamente a estrutura interna dos equipamentos eletrônicos possibilitando a diminuição do tamanho e peso deles e assim os tornou móveis como também gerou o contexto de conectividade perene. Atualmente muitas pessoas com seus smartphones e outros equipamentos móveis vivem em uma constância online que tem modificado cada vez mais a forma do comportamento das pessoas se comunicarem, trabalharem, estabelecerem relações sociais e expressarem suas opiniões sobre uma gama de assuntos pela rede web. ${ }^{8}$

Outro ponto instigante para pensar a descrição do campo digital é a temporalidade. As mudanças e os movimentos de como esse campo online vai se constituindo em um processo de continuidade e descontinuidade das relações sociais que ali estão sendo estabelecidas. O Portal Globo.com surgiu em 20 de março de 2000 e, ao longo do tempo, foi alocando várias revistas no formato de sites de diferentes modalidades que vão do entretenimento ao jornalismo. Somam-se ao conteúdo os blogs. Antes de se tornar um portal, em julho de 1996, houve o lançamento do Globo Online, o site do jornal O Globo, o primeiro site de notícias do Grupo Globo na internet. Segundo as informações da página

\footnotetext{
${ }^{8}$ Em 2014 o acesso à internet é realizado em maior quantidade por smartphones ou celulares do que por computadores de mesa ou notebook, o que vem provar um cenário de uma sociedade em que as pessoas se encontram cada vez mais em constância online proporcionado pela mobilidade dos aparelhos de telefone celular (IBGE 2016).
} 
História do Grupo Globo (2018), a empresa Globo, no momento hospeda quase 700 sites entre eles próprios e outros filiados. ${ }^{9}$

O recorte temporal das matérias sobre transexualidade consistiu como marco a entrada da participante transexual do Big Brother Brasil 11, Ariadna Thalia da Silva Arantes, em 2011. Após a sua participação no reality show observou-se uma maior evidência de matérias que falavam sobre transexualidade no Portal da Globo.com. As matérias que envolviam pessoas trans discutiam, por exemplo, o uso de banheiro em espaços públicos, candidatas ao Exame Nacional do Ensino Médio, relação entre responsáveis e crianças transexuais, celebridades trans e seus relacionamentos com famosos, concursos de beleza como os de Miss, modelos de passarela, entre outros. A linha do tempo das matérias anterior à participação de Ariadna como o início do Portal Globo.com em 2000 assim como o advento das redes sociais do Facebook considera quatro recortes temporais:

1. Do ano 2000 a 2006 (início do Portal Globo.com; com raríssimas matérias sobre transexualidade e nenhum comentário; essa fase é anterior ao início da pesquisa).

2. Do ano de 2007 a 2011 (período "pré-Ariadna no BBB 11", menor frequência de matérias e ainda com tom anedótico e de curiosidade sobre transexualidade e já com comentários mais expressivos; essa fase é anterior ao início da pesquisa).

3. Do ano de 2011 a 2014 (período "pós - Ariadna BBB no 11", maior frequência e enfoque mais político e de cidadania de matérias sobre transexualidade, essa fase é anterior ao início da pesquisa;).

4. Do ano de 2015 a 2018 (período "pós - Ariadna no BBB 11", aumento significativo de frequência e debate mais político de matérias sobre a transexualidade; luta mais organizada na rede social Facebook, força do discurso de ódio na internet; essa fase é durante o desenvolvimento da pesquisa).

A observação imersiva se deu nos anos de 2015-2018. Portanto, há uma linha temporal longa e complexa característica do trabalho antropológico, pois enquanto algumas matérias e postagens foram analisadas em tempo real, outras ainda remontam ao um passado pretérito. É um desafio de trabalhar nessa corda bamba que separa o passado do presente

\footnotetext{
${ }^{9}$ O Portal Globo.com é pertencente ao Grupo Globo que anteriormente era chamado de Organizações Globo; atualmente é o maior conglomerado de mídia e comunicação do Brasil e da América Latina que tem como sua principal empresa a TV Globo que também é a maior do país e uma das maiores do mundo. O Grupo Globo pertence à Família Marinho, que hoje é comandada pelos sucessores do já falecido jornalista Roberto Marinho que foi herdeiro de seu pai Irineu Marinho.
} 
bem como por ocasião da feitura no online. Então está equilibrando-se na tênue linha do tempo vai o antropólogo (no digital) "printando", copiando/colando e arquivando as suas observações.

Observou que os anos de 2015 a 2018 foram um período de maior visibilidade para as pessoas trans no material analisado. Nesse período, a frequência das matérias foi aumentando ano após ano no Portal. É preciso destacar que a questão da temporalidade no Portal deve ser pensada e colocada com as questões em confronto com o contexto social e o que ocorre na rede online está articulado com o macrossocial off-line das políticas públicas; movimentos sociais, as leis. As notícias e os temas não aparecem aleatoriamente, estão articulados com o contexto histórico e político naquele momento.

Fui observando em trânsito pela web que entre o fim de 2015 e início de 2016, que o Portal Globo.com tem preferido bloquear, suspender ou até mesmo tirar a caixa de comentários de muitas reportagens, principalmente, daquelas que retratam violência extremas. Possível que isso indique a preocupação da equipe de jornalismo em impedir os comentários de ódio. O número de comentários também varia de uma matéria para outra, de acordo com alguns fatores como: de que forma ela foi repercutida; se teve ou não destaque no campo visual do portal e também em qual parte dele ficou linkada; durante quantas horas ficou exposta e principalmente sobre que temática sobre a transexualidade (direito, violência ou celebridade transexual) a reportagem falava.

De forma geral, as reportagens sobre transexualidade possuem uma caixa com números expressivos de comentários quando comparadas a outras reportagens. Em média elas passam de 100 comentários. Outro dado importante achado durante a pesquisa foi que o primeiro link sobre o caso "'Representei a dor que sentimos', diz transexual 'crucificada' na Parada Gay” (GLOBO 2015: s.p) foi a notícia que mais gerou opiniões na caixa de comentários durante minha imersão online, totalizando 4349 comentários. 


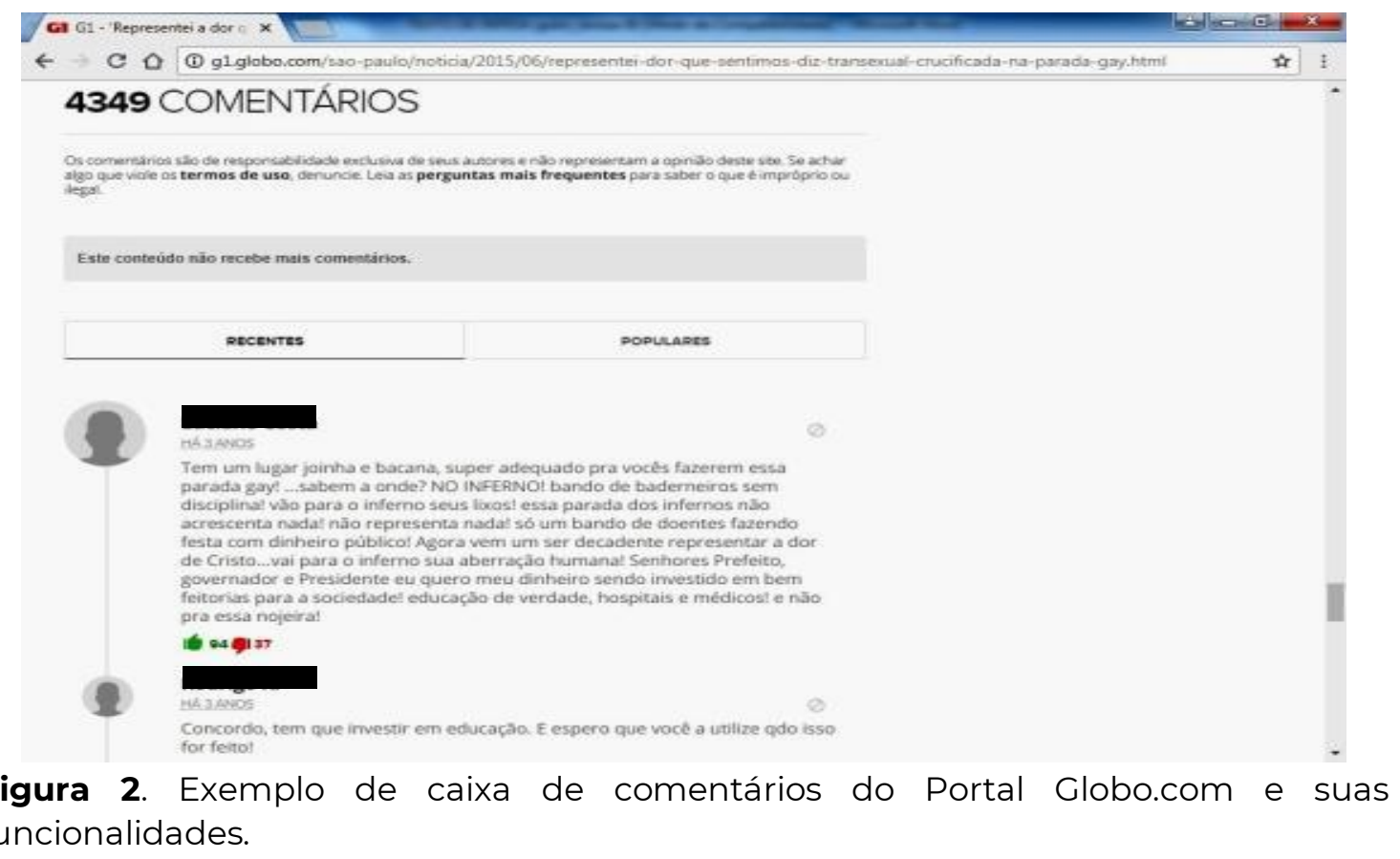

É interessante ressaltar que ao longo da pesquisa houve uma mudança na interface do espaço de comentários no Portal Globo.com. Tornou-se possível comentar um comentário dentro de uma matéria. Tal função é chamada de "entre na conversa". Já, em 2011 além de comentar passou a ser possível "curtir" ou "descurtir"10 um comentário, como também se tornou possível saber quais são os comentários mais recentes e os mais populares.

Assim como o Facebook agregou novos botões ao longo do tempo como a opção "curtir" em 2009, depois em 2013 mais uma funcionalidade a possibilidade de responder um comentário de uma postagem. Em 2016, a rede social libera as "reações", botões em forma de emoji que expressam "Amei", "Haha", "Uau", "Triste" e "Grr", mais do que só a famosa “joinha” ou velho curtir (GLOBO 2016). No mês de maio de 2016 em homenagem ao Dia das Mães foi adicionado o botão "gratidão", uma flor roxa. Em 2017 o Facebook novamente acrescentou mais um emoji, a reação "orgulho" dedicado à comunidade LGBT. O ícone, com as cores do arco-íris, símbolo da luta LGBT ficou entre outros emojis durante o mês de junho. A possibilidade de criar grupos e páginas no Facebook acontece em 2010. Os dois grupos escolhidos, Transgente e Hetero/orgulho proporcionaram novas formas de recepção e interação sobre os conteúdos e temáticas. $\mathrm{O}$ acesso às outras páginas e grupos é, muitas vezes, por meio de compartilhamentos de postagens que circulam nos grupos definidos que compõem a minha análise. E sendo advindos de outras páginas e grupos vão formando uma

\footnotetext{
${ }^{10}$ No Facebook ou no Globo.com, curtir significa que uma pessoa gostou daquilo que foi publicado. Ter várias curtidas em uma postagem é ter uma ideia aceita entre os usuários da rede social ou nas caixas de comentários no portal. Já no portal de notícias existe a possibilidade tanto de curtir (dar um like) como de discutir (dar um dislike) um comentário feito dentro de uma matéria jornalística.
} 
teia digital em torno de uma temática, um circuito de sociabilidade dos usuários, o que me proporciona conhecer por meio dele além dos portais de notícias.

Entre essas mudanças, observa-se que nos últimos anos com o aparecimento das redes sociais a busca de informações tem sido cada vez mais descentralizada dos portais. Segundo o relatório do Reuters Institute e da Universidade de Oxford publicado no Digital New Report (2017) as redes sociais digitais se tornaram as principais fontes de notícias no Mundo, incluindo o Brasil. O Facebook seria o expoente maior de fonte de informações pelos usuários. De acordo ainda com a pesquisa existe uma tendência de as pessoas escolherem mais de uma mídia para acessar informações. Entre as mídias escolhidas, a preferida tem sido as redes sociais digitais como Facebook e o aplicativo WhatsApp que é uma rede social de mensagens instantâneas. Nota-se que são muito frequentes postagens com links de notícias dos portais circularem nas redes sociais; como também sites, como por exemplo, o do portal de notícias G1 pertencente ao Portal Globo.com possuírem página no Facebook. Ademais, há um ícone do Facebook abaixo dos títulos nas matérias locadas no Portal Globo.com para serem compartilhadas na Rede Social. É o Portal Globo.com dentro da Rede Social Facebook. É a Rede Social Facebook dentro do Portal Globo.com.

Em relação ao Facebook, ele foi criado em 2004 e tornou-se a Rede Social mais acessada pelos brasileiros, "ultrapassando o Orkut, durante o mês de dezembro de 2011" (GLOBO 2012: s/p). Hoje é a maior rede social digital do mundo, ou melhor, o maior site de rede social do mundo. De modo que segundo Raquel Recuero (2009) a Internet é também uma rede social mediada por um sistema global de redes de computadores, chamada frequentemente de rede web. A palavra web em inglês significa teia e nesse sentido de rede com o advento da internet a expressão web passou a denominar-se a World Wide Web (WWW) a rede mundial de computadores. Nela os atores sociais (pessoas, instituições ou grupos sociais) estão em conexões (comunicação, fluxo de informações, interações, trocas e laços sociais) o que formam os dois elementos essenciais para definir uma rede social. ${ }^{11}$ Assim, a Internet é uma rede de várias outras redes. Ainda segundo a pesquisadora o Facebook como outros, por exemplo, Fotolog são sites de redes sociais (Facebook) dentro de uma rede social (Internet). Outros sites de redes sociais com dinâmicas próximas do Facebook (2004) foram aparecendo ao logo do tempo o Mysapce (2003), Orkut (2004), Twiter (2006) e mais recentemente o Google+ (2011).

\footnotetext{
${ }^{11}$ Assim, como a rede social não é um evento que surgiu com as redes de computadores o seu conceito também não é novo nas Ciências Sociais. O compartilhar, o vínculo e as trocas sociais são estruturas, ou sistemas sociais que fazem parte da interação social dos seres humanos muito antes das redes sociais online aparecerem. Já, o conceito de rede social surgiu cedo na Sociologia e na Antropologia segundo Silvia Portugal (2007). O termo surge a partir da utilização dos estudos da antropologia britânica em resposta ao modelo estruturalfuncionalista clássico (PORTUGAL 2007).
} 
Segundo Alexa (2018), o Facebook é o quarto site mais acessado e a segunda rede social mais acessada no Brasil, depois da rede social de vídeos Youtube. Entretanto, de acordo com o levantado da companhia, o Facebook ocupa a segunda posição no ranking mundial de site mais acessado apenas atrás do site buscador Google.com.

Para acessar o Facebook há a necessidade de criar um perfil de usuário. É preciso ter um e-mail e uma senha para o login a partir da página principal de cor predominantemente azul. A interface do Facebook consiste basicamente em quatro pilares: o perfil, a feed de notícias, os grupos e as páginas. O visual do Facebook usado no pc ou smathphne são muito parecidos, sem comprometimento do conteúdo independentemente do suporte de aparelho usado. O perfil é composto por apresentação, fotos, vídeos, listas de amigos, compartilhamentos e postagens com "curtidas" e comentários e outras informações sobre o usuário que podem ser ocultadas ou não. Assim como no perfil há uma linha do tempo que são as atualizações de postagens; na feed notícias são as histórias públicas atualizadas que envolvem o usuário como também as dos outros e da sua rede amigos, páginas e grupos.

É preciso ressaltar algumas diferenças entre página e grupo no Facebook. Apesar de ambos terem funcionalidades muito parecidas, somente a pessoa que administra uma página na rede pode postar conteúdo nela ao contrário do grupo em que todos os membros estão habilitados a postar. Contudo tanto nas páginas como nos grupos as pessoas que os acompanham podem curtir e comentar sobre as postagens.

Pensando a partir da recepção pode ser afirmar que a sua mensuração numa página são os números de curtidas, enfim pelos números de seguidores, enquanto o interesse pelo grupo é mensurado pelo número de membros. Entretanto, nem o número de membros e nem mesmo o número de curtidas sejam eles expressivos garantem que tanto um quanto outro se mostrem ativos com postagens e atualizações, um fator essencial na escolha dos dois grupos aqui pesquisados, um que representasse o combater e o outro o lutar pela transexualidade. Como destacado os dois grupos escolhidos Transgente e Hetero/orgulho auxiliaram para amplificar a percepção da recepção da transexualidade a partir do Portal Globo.com. ${ }^{12}$

\section{A descrição dos grupos online}

O grupo Transgente foi criado em de 2013; vale destacar que me tornei membro em agosto de 2014. O grupo é público e em abril de 2018 o grupo constava com 5.005 membros.

\footnotetext{
${ }^{12}$ Tanto o Portal Globo.com como a Rede Social Facebook possuem grande poder hegemônico de comunicação sendo o último em escala global, e o primeiro de forma mais específica no Brasil. Ambos devem ser pensados como atores sociais, uma vez que, representam de forma bastante expressa parte da sociedade, e por isso, tanto um como outro não são mídias neutras e sim veículos midiáticos atravessados de posicionamentos ideológicos que, muitas vezes, se mostram tendenciosos em suas informações, postagens e matérias que compõe a política tanto do portal como da rede social.
} 
No mês de agosto de 2018 houve uma queda no número de membros: 4.762. No início desse ano (2018) eram 4.876 membros. Em 2015 eram 1.879. Na minha última atualização verificada no mês de outubro de 2018 foi de 4.847. O grupo Transgente é administrado principalmente por Letícia Lanz e tem como moderadores; Ângela Autran Dourado e Geraldo Eustáquio de Souza (outro perfil de Letícia Lanz).

A capa (foto) do grupo sempre traz uma referência de luta pelos direitos das pessoas transgêneras. A capa do mês de março de 2018 era sobre o dia internacional da visibilidade trans - 31 de março; onde está escrito "ser transgênero é normal e é legal". A primeira capa postada em 2013 trazia a seguinte frase "o que você é -Transgente - é o que você deve ser". A capa atual do grupo, postada no dia 17 julho de 2018 traz a seguinte expressão "faça amor e não faça a guerra - movimento transgente”.

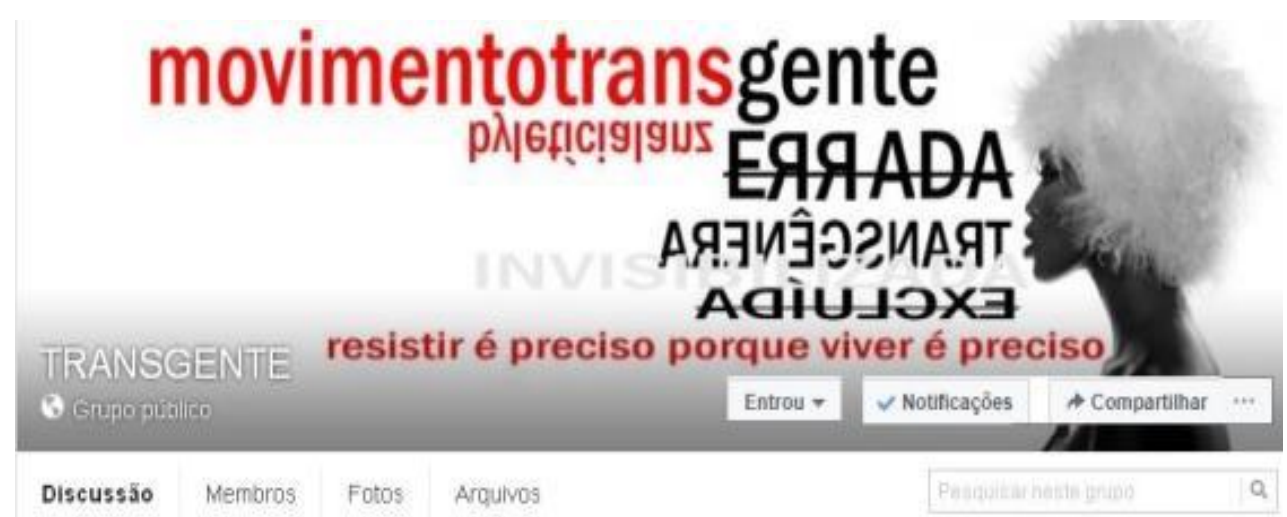

Figura 3. Uma das capas do grupo; como nas demais outras capas enfatiza a resistência. O print foi retirado no dia 20 de junho de 2017.

O grupo possui na sua descrição que "O Movimento Transgente é um movimento inclusivo, não identitário, que se articula em torno da luta pelos direitos civis das pessoas transgêneras". O grupo Transgente possui uma atualização praticamente diária com uma média de mais de cinco postagens por dia, principalmente realizada pela administradora Letícia. Outros membros do grupo também postam, porém com menos frequência. No grupo se encontra pessoas transexuais, travestis e outras autoidentidades de gênero como também pesquisadores de gênero e sexualidade e demais outras pessoas que se identificam com a causa trans. A maioria das postagens do grupo é sobre as normatizações de gênero e sexualidade e dessa maneira são compartilhadas experiências, informações para combater o preconceito contra as pessoas trans e principalmente de se organizarem em uma tentativa de mostrar que elas existem e lutam pelo direito de existirem. Outros assuntos são abordados como, por exemplo, o cenário político atual, mas sempre havendo o link sobre as questões de gênero. Geralmente, na interface dos grupos do Facebook à direita há sugestões de páginas e outros grupos para ser seguidos, curtidos ou membros. Nessas recomendações pelo 
grupo Transgente foi possível conhecer outras páginas e grupos trans, LGBT e feministas. Os assuntos como violência contra as pessoas trans e luta pelos direitos delas que aparecem no Portal Globo.com são transversalizados nas postagens do grupo.

Já, o grupo Hetero/orgulho - H/O foi criado em 2015. O grupo é fechado e seu endereço eletrônico está locado na rede social Facebook. A capa do grupo Hetero/orgulho (que segue abaixo) e como já demonstrada do grupo Transgente é um recurso do Facebook, usado tanto por perfis, páginas e grupos da rede social que permite expressar o que um perfil, página ou grupo gosta e representa. Na figura 04 observa-se que o nome original do grupo foi borrado (efeito chamado de blur realizado em editores de imagens) por razões éticas de mantê-lo camuflado.

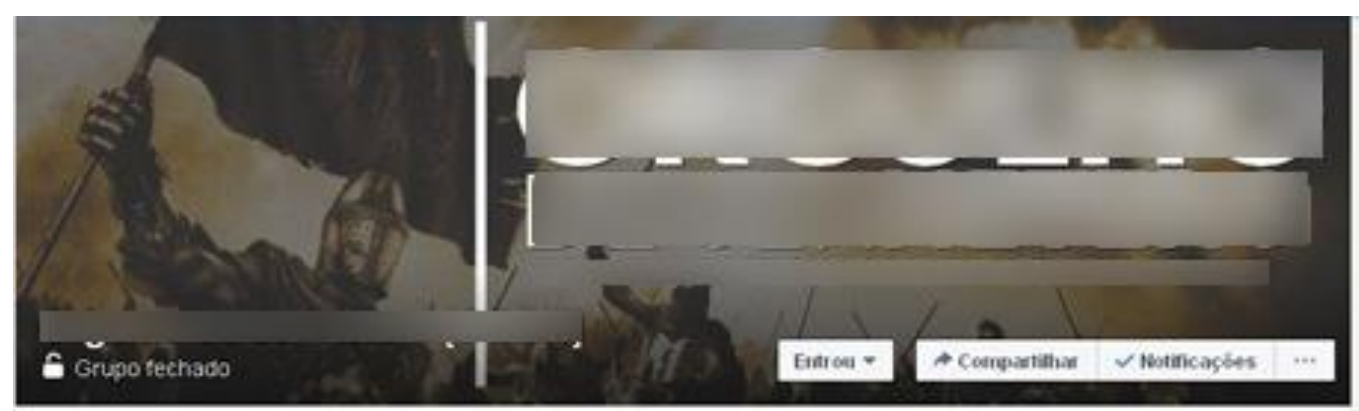

Discusssa Membros Evencos focos arquivos

Figura 4. A capa anterior da atual do grupo $\mathrm{H} / \mathrm{O}$ fazia referência às cenas de guerras de combates medievais. O print foi retirado no dia 20 de junho de 2017.

A capa atual do grupo possui um muro com tijolos acinzentados. A foto da muralha traz o nome do grupo escrito em cores esverdeadas e logo abaixo em letras vermelhas o endereço do grupo. Quando se abre a foto da capa é possível ver também os escritos em vermelhos no canto superior direito escrito "seja bem-vindo e convide seus amigos" e no canto superior esquerdo "respeite as regras e evite ser banido".

Descrevendo ainda sobre as capas dos dois grupos, é interessante destacar que as figuras das capas mostram como já mencionadas, do grupo Transgente é público, isso quer dizer que a visualização de suas postagens é aberta ao público e assim possíveis a membros e não membros. Já, o grupo Hetero/orgulho como é um grupo fechado, dessa forma, a visualização de suas postagens é restrita aos membros. Para haver a visualização delas é preciso ser membro. $\mathrm{O}$ controle das postagens sobrepõe, muitas vezes, as regras que o próprio Facebook permitem como, por exemplo, de postagens que abordam o feminismo, LGBT e partidos de esquerda. A foto da muralha (capa atual) e a grande preocupação com que essas regras sejam cumpridas revela o grupo $\mathrm{H} / \mathrm{O}$ como uma espécie de condomínio fechado heteronormativo e antidemocrático.

Em abril de 2018 o grupo Hetero/orgulho - H/O tinha 43.422 membros. Em 2017 
eram 11.976 membros. Em agosto de 2018 houve uma queda de membros para 41.557. Hoje, na última atualização na data de 28 de outubro de 2018 são 41.229 membros que compõem o grupo. Em uma postagem fixa, o principal administrador do grupo, posta a seguinte mensagem "\# Seja bem-vindo ao melhor grupo de héteros do Facebook". O grupo é administrado por 10 moderadores, entre eles, o administrador principal. No total desses dez moderadores seis são homens e quatro são mulheres. Sobre o administrador principal do grupo há pouca informação em seu perfil pessoal. Na descrição do grupo e como em outras postagens há sempre uma preocupação que as regras sejam cumpridas. Sobre algumas regras, chama a atenção a de número 12, pois o fato de não poder denunciar ao Facebook sem antes consultar os administradores do grupo mostra que a administração do Hetero/orgulho vai sobrepor as próprias normas da Rede Social e assim criar outras normas com maior tolerância à violência, fazendo com que eles medeiem quais conteúdos podem ou não ser postado ou discutido. A de número 10 que é proibido grupos que são nomeados de esquerdista como, por exemplo, feministas, lgbtistas, comunistas, socialistas e intelectuais, enfim aqueles vistos como indesejáveis pelo grupo. Tal proibição também se coloca acima dos direitos constitucionais e mais difícil de ser pensada se fosse aplicada de maneira off-line.

O grupo Hetero/orgulho possui uma atualização de mais ou menos dez postagens por dia. Os membros em sua maioria são homens, mas existe uma participação cada vez mais ativa de mulheres no grupo. Grande parte das postagens do grupo é composta por críticas contra aos movimentos feministas, LGBT e aos partidos de esquerda e tudo que lembra ou se associa com a ideia de comunismo. Não é propriamente uma luta pela heterossexualidade e sim um combate de tudo que problematiza a heterossexualidade, ou seja, é um grupo contra as lutas igualitárias. É uma valorização de "ser hetero" que somente acontece a partir da desvalorização daqueles que não são. Assim, há no grupo uma supervalorização do masculino e a exaltação do homem; contrapondo com uma desvalorização da mulher e do feminino.

As postagens dos membros do grupo centram-se, majoritariamente, no enaltecimento de representantes políticos extremistas de direita, da família (monogâmica, cristã, nuclear e heterossexual) e do uso de armas de fogo como forma de resolver os problemas sociais. Com as sugestões de grupos e páginas dentro do binarismo de gênero e contra os estudos de gênero nas escolas. As matérias do Portal Globo.com ganham destaque nas postagens e compartimentos no grupo. Tais descrições possibilitam um melhor entendimento das relações, das interações e dos vínculos dos usuários com o campo online.

\section{Desafios de uma observação oculta de imersão online}


Como relatado o método de pesquisa usado foi a imersão observante obstrutiva ${ }^{13}$, por meio dela que foi possível chegar as 45 matérias (mais outras 15 dos anos anteriores a 2015) e seus respectivos comentários. Da mesma forma chegou-se aos dois grupos do Facebook com suas postagens, curtidas, compartilhamentos e sugestões de páginas e grupos com o objetivo de perceber outras formas de recepções da transexualidade.

Para analisar esse artefato digital, utilizei diversas técnicas de observação: imersão diária no Portal Globo.com, ora no computador ora no smartphone, o que me rendeu alguns prints de composições das matérias em tempo real (online). Quando se tratou de matérias mais antigas, algumas já levantadas, usei a prática digital de copiar e colá-las em documento Word, editor de texto da Officer da empresa Microsoft, sempre salvando e arquivando em pastas devidamente identificadas. As matérias foram, muitas vezes, pesquisadas através do buscador da própria plataforma usando palavras-chave como "transexualidade" e "transexual". Este recurso foi acionado principalmente nas plataformas como o G1 e Ego que fazem parte do conglomerado Globo.com. Durante grande parte da minha pesquisa, acessei diariamente o Portal Globo.com e o mantinha aberto no computador desde que acordava até dormir. A maioria das matérias levantadas durante a minha imersão online foi por esse meio. Outras por meio de links da rede social Facebook, uma vez que seguia os grupos/páginas em tempo integral. Mesmo assim, assumo que algo da recepção da transexualidade se perdeu em nosso percurso de minha análise. Como relatado os links na internet têm uma estrutura que levam a outros links, por essa razão existe de certa forma uma dificuldade de limitar o campo no online. Por outro lado, são os links que possibilitam um recorrido de caminhos e possibilidades muito mais amplos, graças a essa teia de links. Respeitando a delimitação do campo das reportagens sobre transexualidade no Portal Globo.com; durante esta pesquisa foram levantadas 60 matérias jornalísticas e seus 22.581 comentários e como esses conteúdos eram transversalizados nas postagens dos dois grupos TRANSGENTE e Hetero/orgulho [H/O ${ }^{14}$. Contudo, isso não impedia que eu pudesse ler o conteúdo de um link e chegar a outro e, então, "clicando" nele ir para outra página que até guardava alguma relação com a anterior. O link cria pontes pela rede social digital, uma notícia em um portal é apropriada por outra notícia ou postagem que às vezes é compartilhada. É muito comum que uma postagem em um grupo ou página tornar-se conteúdo de outra página ou grupo de interesses do Facebook. Esse movimento possibilita chegar às outras recepções das transexualidades. Tudo isso me fez pensar de que estava

\footnotetext{
${ }^{13}$ Segundo Robert Kozinets (2006) essa forma de imersão possibilita a observação minuciosa e a coleta de comentários expostos na internet tanto de reportagens como de grupos/páginas do Facebook sem a interação com as pessoas que comentaram

${ }^{14}$ É preciso chamar atenção que alguns comentários, algumas vezes, como até mesmo algumas caixas de comentários com o passar do tempo são removidas, ou porque algum comentarista saiu da Rede ou do cadastro do Portal ou simplesmente porque houve atualização do grupo ou site da matéria, ou ainda por outro motivo.
} 
fazendo um trabalho de bricolagem com as fontes digitais. Não, porque não haja um cuidado com o método, mas por executar uma operação que consiste em remendar coisas ou pedaços, havendo assim arranjos que provocam a sensação de "isto sempre pode servir".

Houve na confecção da pesquisa uma série de desafios na coleta e organização dos dados. A começar, pelo problema de como dar conta da imensidão de comentários, matérias e postagens. Outro desafio se refere à questão de ausência de contato físico direto entre os interlocutores nas mídias digitais, pois se leio um comentário, por exemplo, transfóbico, não se tem como flagrar em que contexto este se dá. Atuei como um lurker, isto é, um observador silencioso e despercebido pelos observados (BRAGA 2006; AMARAL 2010), de forma que não interagi com as pessoas que fazem as postagens com comentários sobre o que elas escreviam.

A imersão em campo é uma antiga prática entre os antropólogos. De acordo com Bronislaw Malinowski (1976) ela é a base da técnica de observação participante e proporciona uma abordagem antropológica meticulosa dos comportamentos sociais da vida cotidiana, e que imergido no macrocosmo social de outra cultura, o antropólogo pode chegar a percebê-la, compreendê-la e descrevê-la. A imersão proporcionada pela Antropologia Digital implica perceber que "continuamos humanos dentro do mundo digital, o digital também provê muitas novas oportunidades para a Antropologia nos ajudar a entender o que significa ser humano" (MILLER; HORTS 2015: 92)

Para Adriana Braga (2006, p.5) qualquer tipo de observação é participante. Dessa maneira, a imersão tendo incluída nela as funções de participar, de observar e de descrever; a torna efetivamente uma experiência de participação no campo pesquisado. A pesquisadora se indaga se o pesquisador lurker em meios digitais pode ser considerado efetivamente como um observador participante: "Então, lurking é participação? Sim, é participação, mas de um tipo especial (...) por reconhecer que, em termos de presença/ ausência, a informação acerca da presença do/a observador/a no setting não está disponível às/aos demais participantes”.

A imersão diminui a distância da recepção e possibilita o aumento crescente do exercício de alteridade para o entendimento do que está acontecendo, o conteúdo de um comentário, de uma postagem ou de um compartilhamento é relevante para compreender a estrutura social que lhes conferem sentido ou significado social. A seleção destes fez com que utilizasse uma espécie de método de garimpagem de dados tanto dos comentários, postagens como das matérias e grupos que filtrados atendessem os parâmetros e as variáveis que a pesquisa buscava nas mídias digitais.

Ainda, falando sobre a imersão de observação oculta, a antropóloga Piia Varis (2014) afirma que os ambientes digitais, principalmente, com o recente aumento das redes sociais trouxeram novas questões a serem discutidas pela antropologia, isso implica que foram necessárias abordar noções importantes, como de "observação participante" também 
chamada de engajamento e a "observação à espreita", isto é, a "observação invisível". Sobre tais questões, a autora vê que a observação é um dos pontos básicos do exercício antropológico, uma vez como já mencionado, é por meio dela que temos o entendimento das práticas e das construções dos significados daquilo que estamos analisando.

Segundo Varis, nos estudos das comunicações digitais sempre vai haver o envolvimento da tela e por isso, torna possível que os pesquisadores possam "melhor" se "esconder" e "participar invisivelmente" sem o conhecimento das pessoas cujas atividades estão sendo observadas - estando totalmente imerso no ambiente e nas atividades em questão analisadas; é como se o antropólogo estivesse usando uma capa de invisibilidade. De acordo com Varis (2014) existem alguns pontos ao redor da questão de invisibilidade que merece ser discutido, entre eles, que a invisibilidade garantida pela tela entre o pesquisador e o pesquisado apresenta uma oportunidade única de coleta dados "naturais", pois os informantes não estão cientes de seu status de informante e, portanto, não modificar seu comportamento por saber que está sendo observado ou porque está interagindo com o pesquisador têm sido uma efetiva forma de abordagem.

Frente a tais colocações de Varis (2014) merece destacar e descrever por meio da minha imersão nas plataformas de como fui aceito no grupo Hetero/orgulho. Como o meu perfil não se enquadraria a descrição do grupo por ter postagens sobre a luta LGBT e feminista como de política esquerdista, além de fornecer informação que sou pesquisador fez com que nem mesmo tentasse adicionar o grupo. No primeiro momento criei um perfil masculino, peguei uma foto de um fotolog argentino de um amigo meu, com a sua autorização. Mas, ao adicionar o grupo, fiquei pendente e depois não fui aceito. Em seguida, criei um perfil feminino, peguei uma foto de uma amiga desse meu amigo, também os informando. Logo que adicionei o grupo, fui "aceito". Com o perfil feminino me mantive a todo instante sem interação com o grupo, apenas observando a dinâmica dos membros nele. Kozinets (2014) chama isso de camuflagem, mesmo que o autor fale mais especificamente sobre a camuflagem dos pesquisados, ela pode-se estender também para a camuflagem do pesquisador. Dessa maneira, usar pseudônimos, nomes e outras maneiras de identificação para não revelar realmente os nomes dos participantes ou criar um perfil para poder ser aceito num grupo para pesquisar e se inserir nele sem que seus interlocutores, os membros do grupo, percebam ou saibam que se trata de um pesquisador são formas de camuflagem.

Pensar o perfil $f a k e^{15}$ nas redes sociais é problematizar as intenções do uso dele, que

\footnotetext{
${ }^{15}$ Observa-se que a figura do fake persiste na rede web e atravessa o discurso da internet. Geralmente, o fake tem guarita de um aparente anonimato. É interessante ressaltar que diferentes tipos de perfis falsos têm sido usado para manipular a opinião pública, entre eles, por exemplo, o bot (abreviação de robot) o chamado robô que seria softwares com tarefas online automatizadas e o ciborgue que são perfis controlados diretamente por humanos com a ajuda de automação, ambos podem atuar tanto maliciosamente (difusão de notícias falsas) como beneficamente (atendimento ao consumidor).
} 
pode ser das mais variadas, e nem sempre provida de má intenção como, geralmente, os fakes são associados. O fake pode ser criado para uma boa intenção, como por exemplo, aqui usado para pesquisar um grupo que, muitas vezes, se utiliza dos próprios perfis fakes para brincadeiras de mau gosto até manipulação de opinião pública, propagação de preconceitos e violências como presenciados no grupo H/O.

Vale dizer que essa imersão que não interagem com os sujeitos não é uma prática que as mídias digitais trouxeram ou que se mostra uma exclusividade delas, ou ainda, que não exista outra possibilidade com imersão interativa nelas. Já que, a observação na espreita pode ser realizada também de forma off-line como, por exemplo, um antropólogo como observador "invisível" analisando as dinâmicas de consumo numa praça de alimentação. Entretanto, como lembra Varis (2014) esse tipo de observação “invisível” nas mídias digitais diferente da do exemplo citado tem uma tela mediando o pesquisador que pode estar oculto e o pesquisado pode desconhecer que está sendo observado. Com isso, como descreve a autora, existem argumentos que consideram ou não a ocultação do observador sem interação uma observação etnográfica pelo menos num sentido tradicional. Diante de tal dilema, a presente pesquisa preferiu tomar este estudo como antropológico e não de fato uma etnografia, sem que isso pudesse desmerecer uma ou outra abordagem, uma vez que ambas têm como principal preocupação descrever por meio do olhar de observação as dinâmicas culturais.

Da mesma forma que, a imersão nas mídias digitais pode não ter interação, o pesquisador muito pode interagir com o pesquisado como, por exemplo, por meio de comentários, postagens, ou ainda em fórum e até mesmo pelo uso de mensagem privadas (ou in-box que consiste no bate-papo privado). Tanto um como outro, o ato de descrever ou detalhar o processo de exercício de observação é primordial para a antropologia.

Diante disso, é importante dizer que mais do que problematizar se a "ocultação" num tipo de "imersão não interativa" com os sujeitos pesquisados pode ser chamada de etnografia, é perceber que esse tipo de abordagem se mostra uma novidade interessante e que deve ser explorada como uma forma de pesquisa eficiente e bem adaptada para entender o fenômeno cultural da internet, principalmente, num cenário de ascensão e força em que as mídias sociais cada vez mais têm tomado nas vidas das pessoas.

Uma abordagem sem interação com os sujeitos pesquisados me possibilitou alguns questionamentos quando estive imerso como lurker. Será que como pesquisador estou realmente invisível? Ou o meu perfil estando ali no grupo e assim poderia ser descoberto? Se o antropólogo na praça de alimentação pode se camuflar como consumidor, poderia o mesmo se camuflar como membro de um grupo na rede social? Existem limites de estar camuflado off-line ou estar camuflado online? Lembrando que o online é complemento do off-line e vice-versa. A imersão oculta é mais vantajosa que a imersão interativa? Jaume 
Soriano (2007) diz que ambas têm suas vantagens e desvantagens.

A forma como me inseri foi por imersão oculta, como retratado, com a necessidade de criar um perfil inventado (camuflado) que me viabilizou estar ali escondido e me preservar como pesquisador, garantindo dessa maneira a minha atuação como observador. Sobre esses pontos da ocultação, Soriano (2007) diz que existem contextos nos quais não é necessário explicar a situação de pesquisador. A questão ética é um dos aspectos mais importantes no navegar online (KOZINETS 2014), primando por essa perspectiva mesmo me camuflando não usei desse instrumento para denunciar, desqualificar ou vazar dados do grupo. Tais informações obtidas foram realizadas de maneira cientificamente correta, por isso a ética se torna preciosa para o exercício do antropólogo no online.

Além disso, uma questão importante na imersão "não interativa" ou/e "oculta" é o papel que a abordagem proporciona de mais neutralidade em relação aos pesquisados, segundo Soriano (2007). Para o autor, a presença do pesquisador pode provocar, no caso de grupos em redes sociais, em um primeiro momento mudanças no teor das postagens e, assim, constrangimentos entre os membros. Nota-se que existe o risco ao comportamento da pessoa mudar por causa da interação e isso muitas vezes coloca-se em cheque a eficiência da observação que também pode comprometer a análise dos dados levantados; tais fatores foram fundamentais por primar pela neutralidade e me manter oculto nos grupos que pesquisei. Se por um lado, a abordagem "não interativa" tem seus benefícios, do outro lado a abordagem interativa também tem os seus benefícios como enfatiza Soriano (2007). Entre eles de poder realizar entrevistas que, segundo Winkin (1998), poderão oferecer momentos de interação mais direta entre o pesquisador com o pesquisado. Além de servir como tentativa de reconstituir a percepção do lugar por meio das interpretações de diferentes usuários na validade de entender os espaços e seus significados sociais, que se constroem nessas interações; e ainda de conseguir por meio do contato com os observados, possíveis caminhos que somente são capazes de serem acessados devido a essa troca e solidariedade entre pesquisador e pesquisado.

É preciso ainda chamar atenção que mesmo não se identificando como pesquisador, as interações do estudioso com os informantes como no simples fato de perguntar ou escrever um comentário pode interferir na espontaneidade da dinâmica do grupo. Estabelecer um diálogo na tentativa de aprofundar uma opinião dada numa postagem pode também trazer desconfiança por parte dos membros, além de tentar induzir para uma reflexão ou até mesmo uma mudança de posicionamento. Todavia, todas essas questões sobre a "interação" deve ser pensada, além de um problema da neutralidade que ela pode proporcionar ou ainda como Kozinets (2014) ressalta que interagir é a melhor forma de conferir as informações, que seria por exemplo, a checagem dos dados com os próprios membros de um grupo e assim fornecer um refinamento dos sentidos sociais colhidos 
tornando a pesquisa mais legítima e com uma maior credibilidade.

A interatividade pode ser também olhada sobre outro prisma, o da imersão oculta, isso quer dizer que mesmo o pesquisador "não interagindo" com os observados, o estudioso pode conseguir captar a interação deles e edificar os sentidos sociais captados. Portanto, mesmo não havendo uma interação em si, o pesquisador pode conseguir levantar até mesmo de forma minuciosa o que os pesquisados pensam, principalmente, nos meios digitais, pois, como já falado, são meios de comunicação que permitem os seus usuários tomarem o protagonismo dentro do processo de comunicação. Assim, as vozes desses observados vão estar presentes nos comentários, postagens, curtidas, entre outras formas produtoras de sentidos sobre algo que estará sendo ali recebido. Entretanto, o fato do pesquisador não interagir com o sujeito para saber, por exemplo, como a transexualidade é recebida por meio de uma entrevista, o estudioso poderá se utilizar de outros recursos como aqui já evidenciados pelo pesquisador neste estudo antropológico. Como Soriano (2007) afirma as vantagens de um papel mais neutro em relação ao pesquisado cria a possibilidade de empregar outros recursos durante a pesquisa de campo. Como no caso desta pesquisa, para captar a recepção da transexualidade fiz a utilização de alguns artefatos como o uso de print, uma atenção mais refinada para as mensurações e uma observação mais detalhada.

A recepção está relacionada com os meios de comunicação, e assim um estudo de como determinada pessoa recebe uma informação vinda de um meio de comunicabilidade. A recepção possui dos mais variados aspectos quali-quantitativos, pois ela pode ser tanto mensurada como não traduzida em números. Tem que ver com dados quantitativos como também qualitativos. Por exemplo, o número de membros dos grupos são um dado quantitativo, porém significam algo, dizem e reforçam discursos sociais sobre a visibilidade trans. O grupo Transgente possuir aproximadamente 4.000 membros, e o Hetero/orgulho 40.000 , não é mera audiência. Isso envolve também a intensidade que essa audiência tem sido recebida. A recepção gera sentidos e muitas vezes, traz algo que pode ser lido como positivo ou como negativo sobre os mais diversos assuntos.

Como tenho relatado, a imersão online traz algumas interessantes percepções antropológicas. Uma delas é a forma particular que os usuários em ambientes digitais vão expressar as suas emoções, muitas delas em forma textual ou por emotions (que são sinais gráficos que representam emoções que podem ser por smiley que são caracteres tipográficos ou que podem ser por emoji que são imagens de sinais e desenhos). Essas expressões não devem ser vistas, ou somente explicadas, pela falta da interação face a face, como ocorre no off-line. São maneiras, justamente, de oferecer mais signos comunicativos às interações, a fim de evitar possíveis mal-entendidos, uma vez que as "pistas sociais" podem ser mais difíceis de serem lidas nas interações mediadas.

Para Nancy Baym (2010) essas formas de linguagens realizadas no online são tão 
formas de linguagens como as utilizadas linguagens face-face, porém são particularidades das mídias digitais. Sendo diferentes expressões de linguagens, não são menos ou mais "autênticas" na forma de representar as subjetividades dos usuários, seus sentimentos e emoções. Elas podem, inclusive, fazer o uso de compartilhamentos que envolvam músicas, textos, imagens e vídeos, além dos emoticons. Todo esse conjunto de linguagem específica do digital - por exemplo, dar um "amei" em uma postagem, ou uma "curtida" em um comentário, ou ainda ter um número alto de "descurtidas" - são recursos que constituem práticas discursivas e, consequentemente, produzem sentidos sociais e políticos.

Mediado por uma tela digital, o antropólogo imerso oculto, pode ver os comentários serem escritos e postados em "tempo real", ou mesmo postagens sendo curtidas e respondidas, ou ainda presenciar gradualmente o número de compartilhamentos crescendo e a caixa de comentários aumentando e, se não printados (copiados) naquele momento que ocorrem, posteriormente, poderão ser conferidos, pois estarão registrados, mesmo que apenas temporariamente.

\section{A confecção de uma pesquisa online, ou considerações finais}

É momento de juntar os links e deixar uma conexão em aberto. Ficar imerso por quatro anos (2015-2018) em ambientes online fez com que olhasse o Portal como um grande quadro composto por outros quadros. Alguns desses pequenos quadros formados por sites, blogs e outros maiores como os portais dentro de um Portal maior. Fez perceber o Portal Globo.com como um conglomerado que carrega dentro dele portais, sites, blogs, com os mais diversos links formando assim um grande mosaico composto por matérias, fotos, anúncios entre outros elementos digitais internos com conexões externas como, por exemplo, com as redes sociais, o Facebook, um poderoso canal de opinião, inclusive de organização tanto para luta (Transgente) e como para o combate (Hetero/orgulho) da existência de determinados grupos sociais.

Do plim plim para o click click (bordão usado no lançamento do Globo.com) traz um olhar para as mídias digitais tal como propõe Larissa Pelúcio (2015) e Nancy Baym (2010) de percebê-las como espaços de disputas simbólicas, circulação de informações e textualizações de subjetividades que vem transformando as relações pessoais e sociais no mundo contemporâneo. De certo, antes era o que a mídia (convencional) fazia com a gente. Hoje é o que a gente faz com a mídia (digital). Em outras palavras, a mídia digital traz mais intrinsecamente a interação do receptor com o emissor e tem inegavelmente a internet como o seu ápice a partir da WEB 2.0 que temos essa possibilidade da produção de conteúdo ${ }^{16}$, e,

\footnotetext{
${ }^{16}$ Os estudos de André Lemos (2002), por exemplo, mostram como a web 2.0 proporcionou uma interatividade muito maior para que a construção de conteúdo, troca e propagação de informações demandassem cada vez
} 
mais tarde, os celulares smartphones que por terem acesso à rede web um dispositivo de interatividade que pode ser acionado em tempo integral e independente do lugar, o que não se torna um exagero dizer que é uma extensão quase corporal.

As estratégias de pensar o online ainda se valem da "velha" prática da observação, imersão e descrição para entender esse "novo" intermediário pela tela digital. Falar de recepção mesmo embora ela não se reduza a isso, é falar de opinião, e dificilmente outro meio de comunicação conhecido pelo ser humano até então, a opinião tornou-se tão facilmente disseminável para o restante da sociedade como as mídias digitais. Talvez, nunca ter uma opinião representou tanto, desse modo, restringir o estudo de imersão em uma mídia digital apenas aos aspectos quantitativos puros significa não conseguir captar de forma mais apurada o quanto que a recepção é discursiva, com isso, produtora de sentidos. Aí que está, decerto, o exercício do/a antropólogo/a na malha digital: reunir os retalhos que a compõe e lançar-se estrategicamente nesse campo tão desafiante e tão conectado em nós.

\section{Fontes}

ALEXA. Ranking dos sites mais acessados no Brasil. Disponível em:< https://www.alexa.com/topsites/countries/BR>. Acesso em: 15 abr.2018.

GLOBO. In: G1 (2008). O que é: Portal. Disponível em:< http://g1.globo.com/Noticias/0,,MUL414442-15524,00-O+QUE+E+PORTAL.html >. Acesso em: 20 abr.2018.

GLOBO. In: In: G1 (2008 b). Globo.com estreia portal para iPhone e outros smartphones. Disponível em:< http://g1.globo.com/Noticias/Tecnologia/0,,MUL774442-6174,00GLOBOCOM+ESTREIA+PORTAL+PARA+IPHONE+E+OUTROS+SMARTPHONE S.html>. Acesso em: 20 abr.2018.

GLOBO. In: G1 (2015). "'Representei a dor que sentimos', diz transexual 'crucificada' na Parada Gay” (GLOBO, 2015, s.p). Disponível em < http://g1.globo.com/saopaulo/noticia/2015/06/representei-dor-que-sentimos-diz-transexual-crucificada-naparada-gay.html>. Acesso em: 08 jun. 2015.

GLOBO. In: G1. (2012). Facebook passa Orkut e vira maior rede social do Brasil, diz pesquisa. Disponível em: < http://g1.globo.com/tecnologia/noticia/2012/01/facebookpassa-orkut-e-vira-maior-rede-social-do-brasil-diz-pesquisa.html >. Acesso em: 17 jun. 2017.

GLOBO. In: G1. (2016). Facebook libera cinco novos botões alternativos ao 'curtir'. Disponível em: < http://g1.globo.com/tecnologia/noticia/2016/02/facebook-liberacinco-novos-botoes-alternativos-ao-curtir.html >. Acesso em: 03 jun. 2016.

mais o ritmo da contemporaneidade; diferente da web 1.0 que se caracterizava de forma menos interativa e mais estática. 
GRUPO GLOBO. História do Grupo Globo. Disponivel em:< https://robertomarinho.globo.com/hgg/>. Acesso em: 10 set. 2018.

INSTITUTO BRASILEIRO DE GEOGRAFIA E ESTATÍSTICA (IBGE). Acesso à internet e à televisão e posse de telefone móvel celular para uso pessoal: 2014. Coordenação de Trabalho e Rendimento - Rio de Janeiro: IBGE, 2016. Disponível em: <http://goo.gl/q1PhEG>. Acesso em: 05 dez. 2016.

\section{Referências Bibliográficas}

AMARAL, Adriana da Rosa. (2010). Etnografia na pesquisa em cibercultura. Limites e insuficiências metodológicas. Revista USP, v.1, p. 122-135.

BAYM, Nancy K. (2010). Personal Connections in the Digital Age. Cambridge: Polity Press.

BRAGA, Adriana Andrade; GASTALDO, Édilson. (2009). O Legado de Chicago e os Estudos de Recepção, Usos e Consumos Midiáticos. Revista FAMECOS, v. 39, p. 78-84.

BRAGA, Adriana Andrade. (2006). Técnica etnográfica aplicada à comunicação online: uma discussão metodológica. UNIrevista (UNISINOS. Online), v. 1, p. 1-11.

JUNGBLU, Airton Luiz. (2004). A heterogenia do mundo on-line: algumas reflexões sobre virtualização, comunicação mediada por computador e ciberespaço. Horizontes Antropológicos, Porto Alegre, ano 10, n. 21, p. 97-121.

KOZINETS, Robert V. (2006). Click to connect netnography and tribal advertising. Journal of Advertising Research. p. 279-288.

KOZINETS, Robert V. (2014). Netnografia: realizando pesquisa etnográfica online. Porto Alegre: Penso.

LEMOS, André. (2002) Cibercultura. Porto Alegre: Sulina.

MAGNANI, José Guilherme C. (2002), "De perto e de dentro: notas para uma etnografia urbana”, Revista Brasileira de Ciências Sociais, vol17, n.49.

MALINOSWKI, Bronislaw. (1976). Os Argonautas do Pacífico Ocidental. São Paulo: Abril Cultural.

MARTÍN-BARBERO, Jesús. (1987). De los medios a las mediaciones. Barcelona: Gustavo Gili.

MILLER, Daniel; HEATHER, A. Horst. (2015). O Digital e o Humano: prospecto para uma Antropologia Digital. Parágrafo, v. 2, n. 3, pp.91-111.

MILLER, Daniel; HEATHER, A. Horst. (2012). Digital Anthropology. London, UK/New York, USA: Berg.

MISKOLCI, Richard. (2011). Novas conexões: notas teórico-metodológicas para pesquisas sobre o uso de mídias digitais. Cronos, vol.12, n.2, p. 09-22.

MISKOLCI, Richard. (2016). Sociologia Digital: notas sobre pesquisa na era da conectividade. Contemporânea. v. 6, n. 2 p. 275-297. 
MISKOLCI, Richard. (2014). San Francisco e a nova economia do desejo. Lua Nova, São Paulo, vol.91, p.269-295.

PELÚCIO, Larissa; PAIT, Heloísa; SABATINE, Thiago. (Orgs) (2015). No emaranhado da rede: gênero, sexualidade e mídia, desafios teóricos e metodológicos do presente. São Paulo: Annablume.

PELÚCIO, Larissa. (2015). Narrativas infiéis: notas metodológicas e afetivas sobre experiências das masculinidades em um site de encontros para pessoas casadas. Cadernos Pagu, v. 01, p. 31-60.

PORTUGAL, Sílvia. (2007). Contributos para uma discussão do conceito de rede na teoria sociológica. Oficina do CES n. ${ }^{0271}$. Março de 2007. Disponível em:< file://C:/Users/Usuario/Downloads/271.pdf>. Acesso em 10 jun 2017.

RECUERO, Raquel. (2009). Redes sociais na internet. Porto Alegre: Sulina, 2009.

SORIANO, Jaume. (2007). Las nuevas reglas de la etnografia de la comunicación Disponível em: <http://www.portalcomunicacion.com/esp/n_aab_lec_1.asp?id_llico=30>. Acesso em: 10 ago. 2018.

STRATHERN, Marilyn. (2014). O efeito etnográfico e outros ensaios. São Paulo: Cosac Naify.

VARIS, Piia. (2014). Digital ethnography. Tilburg Papers in Culture Studies, Paper 104. Tilburg University.

WINKIN, Yves. (1998). Descer ao campo. In: SAMAIN, Etienne (org.). A nova comunicação: da teoria ao trabalho de campo. São Paulo: Papirus.

sobre o autor

\section{Luiz Augusto Mugnai Vieira Júnior}

Cientista Social. Doutor em Ciências Sociais pela Universidade Estadual Paulista "Júlio de Mesquita Filho" - UNESP. Docente na Universidade Paranaense - UNIPAR.

Recebido em: 30/09/2020

Aceito para publicação em: 04/12/2020 